\title{
DAYA TERIMA KONSUMEN TERHADAP PRODUK STIK BIJI NANGKA BERBAGAI RASA
}

\author{
Consumer's Accepted Power to Stick Products of Jackfruit Seeds in Various Flavors
}

\author{
Kusti Indrianti $^{1)^{*}}$, Karina Chika Wulandari ${ }^{1)}$, Nofalia Kholfatul Anggraeni ${ }^{1)}$, \\ Kevin Jans Saito ${ }^{1)}$, Noer Sizeh ${ }^{2)}$, Irfany Rupiwardani ${ }^{3)}$ \\ ${ }^{1)}$ Mahasiwa S1 prodi kesehatan lingkungan, Stikes Widyagama Husada \\ ${ }^{2)}$ Mahasiwa S1 prodi keperawatan, Stikes Widyagama Husada \\ ${ }^{3)}$ Staf Pengajar prodi kesehatan lingkungan, Stikes Widyagama Husada \\ email : febikristi123@gmail.com
}

\begin{abstract}
Jackfruit seeds have high nutrient content such as carbohydrates and proteins, so they can be used as a potential food ingredient. One of the food product ingredients can be in the form of concrete seed sticks and among the product community in the form of sticks that are very popular with the community. The purpose of this research is to find out the consumer acceptance of stick products of concrete seeds in various flavors. The non-parametric statistical method uses the Friedman Test and the determination of the best treatment uses the index of effectiveness. The results showed that the best combination of treatments on consumer acceptance of organoleptic concrete seed sticks was obtained from spicy-flavored concrete seed sticks with a product value of 0.48 with the following characteristics: average panelist preference for taste 4.32; 2.52 color and 2,96 flavor.
\end{abstract}

Keywords: consumer acceptance, jackfruit seed sticks

\begin{abstract}
ABSTRAK
Biji nangka memiliki kandungan gizi yang tinggi seperti karbohidrat, dan protein, sehingga dapat dimanfaatkan sebagai bahan pangan yang potensial,. Salah satu bahan produk pangan tersebut dapat berupa stik biji beton dan dikalangan masayarakat produk yang berupa stik sangat digemari masyarakat. Tujuan dari penelitian ini adalah untuk mengetahui daya terima konsumen terhadap produk stiki biji beton pada berbagai rasa. Metode statistik non parametrik menggunakan Uji Friedman dan penentuan perlakuan terbaik menggunakan indek efektifitas. Hasil penelitian menunjukkan bahwa kombinasi perlakuan terbaik pada daya terima konsumen terhadap stik biji beton secara organoleptik didapatkan dari stik biji beton rasa pedas dengan nilai produk sebesar 0,48 dengan karakteristik sebagai berikut: rerata nilai tingkat kesukaan panelis terhadap rasa 4,32; warna 2,52 dan aroma 2,96.
\end{abstract}

Kata kunci: daya terima konsumen, stik biji nangka

\section{PENDAHULUAN}

Biji nangka (Artocarpus heterophyllus) memiliki kandungan gizi yang tinggi, sehingga dapat dimanfaatkan sebagai bahan pangan yang potensial. Biji nangka merupakan sumber mineral yang baik. Selain dapat dimakan dalam bentuk utuh, biji nangka dapat diolah menjadi keripik yang enak dan bergizi (Astawan, 2007). Biji buah nangka kaya gizi, terutama kandungan karbohidrat, potassium/kalium, fosfor, dan lemak (Sindumarta, 2012). Komposisi kimiaa biji nangka mengandung pati cukup tinggi, yaitu sekitar 40-50\%.. Kandungan yang terdapat di dalam biji nangka yaitu energi (165 kkal), protein (4,2 gr), lemak ( 0,1 gr), karbohidrat $(36,7$ gr), kalsium (33 mg), fosfor (200 mg), besi (1

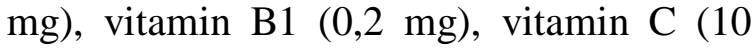
$\mathrm{mg})$, dan air (57,7 gr). Biji nangka dapat 
dimanfaatkan sebagai bahan pangan yang potensial (Nuraini, 2012).

Pengolahan biji nangka menjadi produk makanan merupakan salah satu bentuk usaha memanfaatkan limbah biji nangka sebagai alternative penambah sumber bahan pangan baru. Salah satu cara yang dapat dilakukan adalah dengan memanfaatkan biji nangka menjadi tepung (Rizal et al., 2012; Qomari, 2013). Subtitusi tepung biji nangka berpengaruh nyata terhadap kerenyahan, bentuk, warna, rasa, aroma dan tingkat kesukaan pada produk onde-onde ketawa (Supriadi dan Pangesti, 2014). Limbah biji nangka juga dapat dimanfaatkan menjadi dodol dan kerupuk (Utomo et al., 2016), selain itu juga dapat dimanfaatkan menjadi pangan lain dalam bentuk cookies, hal ini sesuai penelitian Santoso et al. (2015) yang menyatakan hasil uji sifat fisik menunjukkan ada perbedaan warna (L) dan (b) serta tekstur cookies biji nangka segar dan tidak ada perbedaan warna (a). Hasil uji mutu hedonik menunjukkan ada perbedaan rasa tetapi tidak ada perbedaan warna dan tekstur. Hasil uji hedonik menunjukkan tidak ada perbedaan warna, rasa, dan tekstur antara cookies tepung biji nangka segar dan kukus. Menurut Restu et al. (2015) menyatakan bahwa tepung biji nangka juga dapat digunakan sebagai bahan baku untuk pembuatan pia kering.

Pemanfaatan tepung biji nangka dapat digunakan sebagai bahan pengolahan pangan lebih lanjut seperti stik biji beton. Stik merupakan makanan ringan atau jenis kue kering dengan bahan dasar tepung terigu, tepung tapioka atau tepung sagu, lemak, telur serta air, yang berbentuk pipih,atau bulat panjang dan dengan cara penyelesaiannya dengan cara digoreng, mempunyai rasa gurih serta bertekstur renyah sehingga banyak disukai masyarakat (Ramadani dan Suhairi, 2018).

Stik biji nangka dari hasil penelitian ini dinamakan TIKTON (Stik Biji Beton). Alasan penggunaan biji nangka sebagai bahan dari TIKTON adalah inisiatif untuk menciptakan produk TIKTON yang berbeda dari yang lain. TIKTON yang satu ini disediakan berbagai varian rasa yang berasal dari bahan alami yaitu original, pedas dan daun jeruk purut.Penggunaan perasa alami pada produk TIKTON yang dirancang sedemikian rupa bertujuan untuk membedakan produk TIKTON ini dengan produk stik lainnya.

Stik ini memiliki rasa yang renyah, gurih, dan enak, tetapi tetap memperhatikan kebersihan dari produk yang dihasilkan. Produk ini akan dibuat dari limbah biji nangka yang diperoleh dari industri yang bahan bakunya dari buah nangka. Camilan ini aman untuk dikonsumsi karena tidak ada penambahan bahan-bahan aktif yang berbahaya bagi kesehatan, sehingga TIKTON cocok dijadikan cemilan dengan harga yang terjangkau, sehat dan bergizi tinggi. Manfaat camilan ini bagi kesehatna adalah mengandung kalsium yang dibutuhkan untuk pertumbuhan tulang terutama pada anak-anak dan mencegah osteoporosis. Penelitian ini akan menganalisis daya terima konsumen terhadap produk stik biji nangka pada nerbagai rasa.

\section{BAHAN DAN METODE}

\section{Bahan}

Bahan yang digunakan dalam penelitian ini adalah tepung terigu, minyakgoreng, tepung tapioca, garam, telur, bawang putih, soda kue, margarin, daun jeruk purut dan cabe rawit.

\section{Alat}

Alat-alat yang digunakan dalam penelitian ini meliputi, penggiling mie, baskom, sealer, wajan, kompor, nampan, timbangan, meja lipat, penggiling daging, spatula, pisau, serok, gunting, tabung gas LPG, dan panci.

\section{Rancangan Penelitian}

Rancangan yang digunakan dalam penelitian ini menggunakan produk stik biji beton berbagai rasa yaitu ; $\mathrm{B} 1=$ stik biji beton tanpa rasa (original), $\mathrm{B} 2=$ stik biji 
beton rasa daun jeruk, dan B3 = stik biji beton rasa pedas.

\section{Pengamatan}

Pengamatan dilakukan terhadap produk stik biji beton berbagai rasa (warna, rasa dan aroma) dari 25 panelis yang tidak terlatih.

\section{Analisis Data}

Data hasil uji organoleptik dianalisis dengan metode statistik non parametrik menggunakan Uji Friedman dengan $(\alpha=$ 0,05), sedangkan perlakuan terbaik menggunakan indek efektifitas.

\section{HASIL DAN PEMBAHASAN}

\section{Warna}

Hasil uji organoleptik menyajikan bahwa rerata ranking kesukaan panelis terhadap warna dari stik biji beton berbagai rasa berkisar antara 2,08-4,04. Semakin tinggi rerata ranking kesukaan panelis, maka tingkat kesukaan panelis terhadap warna semakin besar. Tabel 1 memperlihatkan rerata ranking tingkat kesukaan panelis terhadap warna.

Tabel 1. Rerata tingkat kesukaan panelis terhadap warna

\begin{tabular}{lc}
\hline \multicolumn{1}{c}{ Kombinasi Perlakuan } & Rerata \\
\hline stik biji beton tanpa rasa (original) & 4,04 \\
(B1) & \\
stik biji beton rasa daun jeruk (B2) & 2,08 \\
stik biji beton rasa pedas (B3) & 2,52 \\
\hline
\end{tabular}

Tabel 1 memperlihatkan rerata nilai kesukaan panelis terhadap warna pada berbagai rasa mempunyai nilai terendah sebesar 2,08 dari kombinasi perlakuan stik biji beton rasa daun jeruk (B2). Nilai tertinggi tingkat kesukaan panelis terhadap warna sebesar 4,04 didapatkan dari stik biji beton tanpa rasa (original).

Hasil analisis Uji Friedman $(\alpha=0,05)$ berdasarkan uji perbandingan pada berbagai kombinasi perlakuan pada rasa memberikan pengaruh nyata terhadap rerata kesukaan warna terhadap kombinasi perlakuan stik biji beton berbagai rasa. Kombinasi perlakuan terbaik tingkat kesukaan panelis terhadap warna diperoleh dari kombinasi perlakuan stik biji beton rasa daun jeruk, warna yang ditimbulkan oleh produk stik biji beton tanpa rasa ini sangat menarik yaitu coklat muda.

\section{Rasa}

Hasil uji organoleptik menyajikan bahwa rerata ranking kesukaan panelis terhadap rasa dari kombinasi perlakuan stik biji beton berbagai rasa berkisar antara 2,724,32. Semakin tinggi rerata ranking kesukaan panelis, maka tingkat kesukaan panelis terhadap rasa semakin besar. Tabel 2 memperlihatkan rerata ranking tingkat kesukaan panelis terhadap rasa.

Tabel 2 memperlihatkan rerata nilai kesukaan panelis terhadap rasa pada berbagai kombinasi perlakuan sebesar 2,72 dari kombinasi perlakuan stik biji beton rasa daun jeruk (B2). Nilai tertinggi tingkat kesukaan panelis terhadap rasa sebesar 4,323 didapatkan dari stik biji beton rasa pedas (B3).

Tabel 2. Rerata tingkat kesukaan panelis terhadap rasa

\begin{tabular}{ll}
\hline \multicolumn{1}{c}{ Kombinasi Perlakuan } & Rerata \\
\hline stik biji beton tanpa rasa (original) & 3,28 \\
(B1) & \\
stik biji beton rasa daun jeruk (B2) & 2,72 \\
stik biji beton rasa pedas (B3) & 4,32 \\
\hline
\end{tabular}

Hasil analisis Uji Friedman $(\alpha=0,05)$ berdasarkan uji perbandingan pada berbagai kombinasi perlakuan memberikan pengaruh nyata terhadap rerata kesukaan rasa terhadap kombinasi perlakuan stik biji beton berbagai rasa. Kombinasi perlakuan terbaik tingkat kesukaan panelis terhadap rasa diperoleh dari kombinasi perlakuan stik biji beton rasa pedas (B3). Menurut panelis stik biji beton rasa pedas sangat digemari oleh panelis, karena mayoritas sangat menyukai rasa pedas 


\section{Aroma}

Hasil uji organoleptik menyajikan bahwa rerata ranking kesukaan panelis terhadap aroma dari kombinasi perlakuan stik biji beton berbagai rasa berkisar antara 2,48-3,8. Semakin tinggi rerata ranking kesukaan panelis, maka tingkat kesukaan panelis terhadap aroma semakin besar. Tabel 3 memperlihatkan rerata ranking tingkat kesukaan panelis terhadap aroma.

Tabel 3. Rerata tingkat kesukaan panelis terhadap aroma

\begin{tabular}{lc}
\hline \multicolumn{1}{c}{ Kombinasi Perlakuan } & Rerata \\
\hline $\begin{array}{l}\text { stik biji beton tanpa rasa (original) } \\
\text { (B1) }\end{array}$ & 2,48 \\
\hline stik biji beton rasa daun jeruk (B2) & 3,8 \\
\hline stik biji beton rasa pedas (B3) & 2,96 \\
\hline
\end{tabular}

Tabel 3 memperlihatkan rerata nilai kesukaan panelis terhadap aroma pada berbagai kombinasi perlakuan mempunyai nilai terendah sebesar 2,48 dari kombinasi perlakuan stik biji beton tanpa rasa (original) (B1). Nilai tertinggi tingkat kesukaan panelis terhadap aroma sebesar 3,8 didapatkan dari kombinasi perlakuan stik biji beton rasa daun jeruk (B2).

Hasil analisis Uji Friedman $(\alpha=0,05)$ berdasarkan uji perbandingan pada berbagai kombinasi perlakuan memberikan pengaruh nyata terhadap rerata kesukaan aroma terhadap kombinasi perlakuan stik biji beton berbagai rasa. Kombinasi perlakuan terbaik tingkat kesukaan panelis terhadap aroma diperoleh dari kombinasi perlakuan stik biji beton rasa daun jeruk (B2). Menurut panelis penambahan daun jeruk memberikan aroma yang sangat wangi dan menyegarkan, sehingga menimbulkan selera untuk memakan stik biji beton.

\section{Pemilihan Perlakuan Terbaik}

Penentuan perlakuan terbaik produk stik biji beton dengan berbagai rasa dilakukan dengan menggunakan metode indeks efektivitas. Hasil uji penentuan kombinasi perlakuan terbaik diperlihatkan pada Tabel 4.
Tabel 4. Nilai produk perlakuan terbaik

\begin{tabular}{|c|c|c|c|c|}
\hline $\begin{array}{l}\text { Kombinasi } \\
\text { Perlakuan }\end{array}$ & Warna & Rasa & Aroma & $\begin{array}{c}\text { Nilai } \\
\text { Produk }\end{array}$ \\
\hline $\begin{array}{l}\text { stik biji beton } \\
\text { tanpa } \\
\text { (original) }(\mathrm{B} 1)\end{array}$ & 4,04 & 3,28 & 2,48 & 0.441 \\
\hline $\begin{array}{lll}\text { stik } & \text { biji } & \text { beton } \\
\text { rasa } & \text { daun } & \text { jeruk } \\
\text { (B2) } & & \\
\end{array}$ & 2,08 & 2,72 & 3,8 & 0.390 \\
\hline $\begin{array}{l}\text { stik biji beton } \\
\text { rasa pedas }(\mathrm{B} 3)\end{array}$ & 2,52 & 4,32 & 2,96 & $0.480 *$ \\
\hline
\end{tabular}

*=Perlakuan terbaik

Tabel 4 memperlihatkan hasil uji perlakuan terbaik didapatkan dari kombinasi perlakuan stik biji beton rasa pedas (B3) dengan nilai produk sebesar 0,48 dengan karakteristik sebagai berikut: rerata nilai tingkat kesukaan panelis terhadap rasa 4,32; warna 2,52 dan aroma 2,96.

\section{KESIMPULAN}

Kombinasi perlakuan terbaik secra organoleptik diperoleh dari kombinasi perlakuan stik biji beton rasa pedas (B3) dengan nilai produk sebesar 0,48 dengan karakteristik sebagai berikut: rerata nilai tingkat kesukaan panelis terhadap rasa 4,32; warna 2,52 dan aroma 2,96.

\section{UCAPAN TERIMA KASIH}

Penulis mengucapkan terima kasih kepada seluruh pihak yang telah membantu dalam pelaksanaan kegiatan PKM dan seluruh pihak yang telah membantu dalam penelitian ini terutama kepada DPRM Dikti dan STIKES Widyagama Husada Malang.

\section{DAFTAR PUSTAKA}

Astawan, M. (2007). Tetap sehat dengan produk makanan olahan. Tiga Serangkai. Surakarta.

Nuraini, D.N. (2011). Aneka Manfaat Bijibijian. Sidoarjo: Penerbit Gava Media.

Qomari, F. (2013). Pengaruh substitusi tepung biji nangka terhadap sifat organoleptik dan sifat kimia kerupuk. Jurnal Tata Boga, 2(1).

Ramadani, S., \& Suhairi, L. (2018). Karakteristik organoleptik stik biji 
nangka (artocarpus heterophyllus) dalam pembuatan stik biji nangka. Jurnal Ilmiah Mahasiswa Pendidikan Kesejahteraan Keluarga, 3(2), 48-56.

Restu, N., Damiati, M.K. \& Ekayani, I.A.P. H. (2015). Pemanfaatan tepung biji nangka menjadi kue pia kering. Bosaparis 3(1).

Rizal, S., Surmarlan, S.H. \& Yulianingsih, R. (2013). Pengaruh konsentrasi natrium bisulfit dan suhu pengeringan terhadap sifat fisikkimia tepung biji nangka (Artocarpus heterow22phyllus). Jurnal Bioproses Komoditas Tropis, 1(2), 1-10.

Santoso, M. T., Hidayati, L., \& Sudjarwati, R. (2015). Pengaruh perlakuan pembuatan tepung biji nangka terhadap kualitas cookies lidah kucing tepung biji nangka. Teknologi dan Kejuruan, 37(2).

Sindumarta, D. (2012). Awet muda dengan durian dan buah-buahan khas nusantara. Yogyakarta: Grafindo Litera Media.

Supriadi, A., \& Pangesti L.T (2014). Pengaruh substitusi tepung biji nangka (Artocarpus heterphyllus) terhadap mutu organoleptik kue onde-onde ketawa. Jurnal Tata Boga, 3(1), 225-233

Utomo, D., Murtadlo, K., \& Novia, C. (2016). Pemanfaatan limbah biji nangka menjadi dodol dan kerupuk. Teknologi Pangan: Media Informasi dan Komunikasi Ilmiah Teknologi Pertanian, 7(3). 